\title{
Ethical Indigenous Economies
}

\author{
Dara Kelly \& Christine Woods
}

\begin{abstract}
AвSTRACT In this article, the authors argue that trans-systemic knowledge system analysis of Indigenous-to-Indigenous economics enables generative thinking toward Indigenous futures of economic freedom. The authors apply a trans-systemic lens to critically analyze persistent development philosophy that acts as a barrier to the advancement of Indigenous economic development thinking. By exploring ways in which colonial discourse entraps Indigenous nations within circular logic in service of a normative centre, the authors clarify the need for a new economic logic. Shifting to trans-systemic knowledge systems analysis to include diverse insights from Māori and other Indigenous economic philosophy, the authors show that it is not profit and financial growth that matters in and of itself. Rather, according to Indigenous definitions of wealth, economic freedom and development are constituted by value creation that aligns with Indigenous worldviews and principles. Indigenous economic knowledge centred on relationship, reciprocity, and interconnectedness fosters Indigenous economic freedom.
\end{abstract}

KeYWords Indigenous economics, trans-systemic Indigenous knowledge, ethical economies, Indigenous economic freedom

According to Mi'kmaw scholar Battiste (2013), trans-systemic knowledge reaches "beyond the two distinct systems of knowledge to create fair and just educational systems and experiences so that all students can benefit from their education in multiple ways" (p.103). Battiste emphasizes new relationships among and between knowledge systems as avenues for transsystemic knowledge to contribute impact and insight. For disciplines less established concerning Indigenous contexts, such as business and economics, we argue that a trans-systemic approach not only requires competence navigating between Anglo-Western and Indigenous business theories, but increasingly calls for navigation among different global Indigenous knowledges. In this article, we expand the application of trans-systemic knowledge systems analysis to the analysis of Indigenous economic development across global Indigenous knowledge systems, including Canada, the United States, and Aotearoa-New Zealand.

Thus, considering Battiste's argument that trans-systemic knowledge comes from 'beyond' two (or more) systems, as we think about trans-systemic knowledge in Indigenous economic contexts, the process of journeying across brings forth a mindset to travel. To travel across time, boundaries, difference and similarity, between communities and nations sparks a process 
that invokes memory through collective intergenerational transmission. At a deep level, trans-systemic knowledges may act as a form of repository for what is and is not useful for future generations. In some ways, trans-systemic knowledge analysis illuminates how ancient wisdom lives in the eternal present through shared experience and memory (Cajete, 1994, 1999; Hēnare, 2011). By preserving an intergenerational Indigenous lens, a trans-systemic method of analysis enables us to see incongruence and inconsistency in the emergence of 'new' scholarly discourse by virtue of the fact that innovative thinking inevitably rests on genealogies of knowledge that came before.

Bartlett et al. (2012) present a framework for moving between Indigenous knowledge and mainstream science in a "Two-eyed Seeing" approach. As part of a methodology for Indigenous-led participatory action research, twoeyed seeing is based on partnership principles embedded within the two-row Wampum belts used by First Nations in eastern Canada. The two rows of beads symbolically record specific agreements, events and expectations for conduct by two parties (Bartlett et al., 2012). Similarly, the two-eyed seeing methodology utilizes dual perspectives to ground research design in Indigenous and non-Indigenous epistemologies. By combining two knowledge systems to meet a challenge or task such as climate change, two-eyed seeing advances strength-based thinking from innovative ideas from both Indigenous and Western science systems. The process of engaging in two-eyed seeing is described as weaving back and forth between systems to find new insights to inform a project in complementary and trans-systemic ways. The weaving metaphor captures the essence of process innovation inherent within Indigenous knowledge systems and is common in articulating Indigenous research methodologies. For example, Kahakalau (2004) develops an emergent Indigenous heuristic technique drawing on Moustakas' (1990) six-step heuristic process. Each step

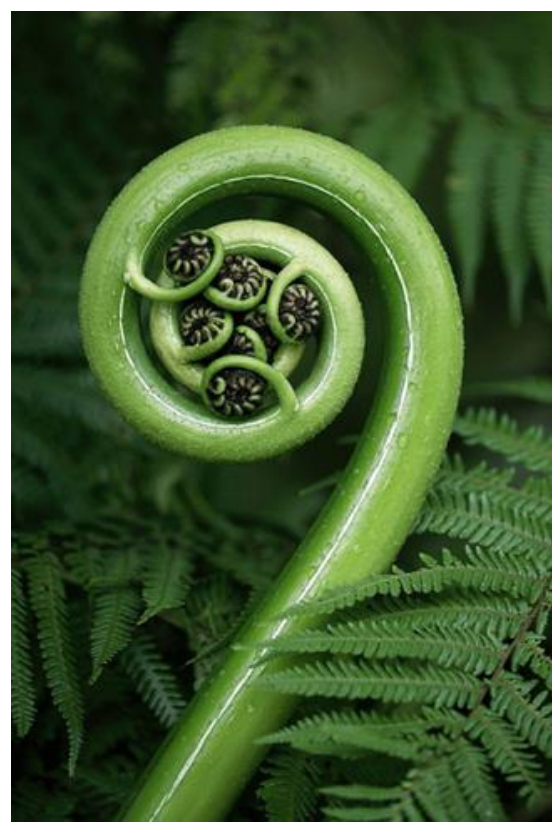

Figure 1. The spiral of the fiddlehead, shown in this image, represents an ethic of reciprocity, interconnectedness and the infinite potential of intergenerational well-being in ethical Indigenous economies. is Indigenized and incorporates Indigenous ways of being to situate research outcomes by, for, and with Indigenous communities. Kahakalau (2004) identifies the role of time as a resource, which means in research, one allows for periods of "marination" in liminal spaces to develop new insights to occur (p. 29). In the discipline of business, writing from a Māori perspective, Nicholson et al. (2019) employ an ambicultural approach to corporate governance in support of five Māori well-beings. Based on the scholarship of Chen and Miller (2010), who propose ways to understand across an East-West divide in management philosophy, an ambicultural approach in Māori business builds on pluralism as a way to holistically integrate multiple sources of knowledge into ethical decision making in organizations. At its heart, 
ambiculturalism encourages intellectual inquiry from a starting place to challenge fundamental or taken for granted assumptions; in the process of simultaneously unlearning and re-learning, an ambicultural approach finds synchronicities in diverse, yet complementary knowledge traditions to generate innovative ways for theorizing.

While there is enormous historical and cultural variance among Indigenous knowledges globally, trans-systemic knowledge systems analysis creates the opportunity for Indigenous nations to imagine what is possible beyond the boundaries of a binary relationship to colonial philosophy. Trans-systemic analysis across Indigenous contexts helps to expand the use of Indigenous-to-Indigenous frameworks for Indigenous economic development. Within the academy, there have been long traditions of global Indigenous knowledge exchanges in education, law, health, and the humanities. In the discipline of business, this work is in nascent stages, not because Indigenous scholars who have been researching in business have not done enough work; instead, because there have not been enough scholars to develop Indigenous perspectives in business across a range of topics. For example, Indigenous entrepreneurship stands out as the area of study within business that has the most empirical and theoretical foundation (Anderson et al., 2006; Colbourne, 2018; Foley, 2003; Henry, 2007, 2017; Maritz \& Foley, 2018; Peredo et al., 2004; ), though Indigenous business scholarship overall is increasing as the global pool of Indigenous business scholars grows.

We employ a trans-systemic analysis method to discourses framing Indigenous economic development in Canada and consider this alongside emerging research on the Māori Indigenous economy in Aotearoa-New Zealand. We ask the following research question: in the evolving landscape of global Indigenous economic development, how does a trans-systemic knowledge system lens enable an expanded vision toward realizing Indigenous well-being economies? To answer this research question, we trace a 50-year discursive theme that continues to inform industry approaches to Canadian Indigenous economic development, introduce current research and thinking on Indigenous economies emerging from Aotearoa-New Zealand, the United States, and Canada and conclude with discussion about the future of Indigenous wellbeing economies informed by a trans-systemic knowledge systems approach.

\section{Aiming Low: Participation and Poverty Alleviation as Economic Reconciliation}

As we consider Indigenous economies within a longer historical landscape of discourses of Canadian Indigenous development — past, present, and future — we consider Harold Cardinal's (1969) analysis of Canadian federal policy leading up to the infamous White Paper in his book, The Unjust Society: The Tragedy of Canada's Indians. Among the many compelling examples of failed federal policy, Cardinal (1969) highlights a particularly illuminating statement in the foreword to the White Paper that reads: "The Government believes that its policies must lead to the full, free and non-discriminatory participation of the Indian people in Canadian society" [emphasis added] (p. 133). To provide context for this choice of language, before the White Paper, the discourse of federal policy had been decisively discriminatory and segregationist in its relations with Indians, encouraging only assimilation and abandonment of Indian identity as a condition for inclusion in Canadian society. Thus, this invitation for Indian participation 
'as you are' might have appeared to signal a considerable shift in perspective. However, this offer was wholly insignificant against the Indian agenda that included such goals as sovereignty, self-determination, compensation for illegal land alienation and reparations for harm done as a result of colonization.

Forty years later, in a 2009 Federal Framework for Aboriginal Economic Development, the Minister for Indian Affairs and Northern Development and Federal Interlocutor for Métis and Non-Status Indians, Honourable Chuck Strahl (2009) introduces the framework as an overview of initiatives to "improve the participation of First Nations, Inuit and Métis people in the Canadian economy" [emphasis added] (preamble). Part of the strategy includes removal of "obstacles to Aboriginal Canadians' full participation in the economy [emphasis added]" (Strahl, 2009 , p. 21). Reading these documents together in 2020 , one would be forgiven if you thought there was a template for notices about Indigenous participation in Canada; the consistency of discourse reveals an underlying body of knowledge and related structures of collective memory in Canadian public policy that has changed little over time.

Since 2009, a 'new' iteration of change in the form of the Truth and Reconciliation Commission of Canada (2015) has given rise to an assortment of reconciliation sub-themes, including economic and business reconciliation. In the Business Reconciliation in Canada Guidebook, appeals to corporate Canada are outlined: "Ensuring Indigenous Peoples play a meaningful and substantial role in the economy [emphasis added] is the most relevant and impactful way forward for economic and business reconciliation in Canada" (Canadian Council for Aboriginal Business, 2019, p. 9). Implicit within this statement are several assumptions. Firstly, with no acknowledgement of the extensive Indigenous economic histories that preceded the arrival of settlers to Canada, the document, intentionally or not, supports an assumption that Indigenous nations are latecomers to the game of economics. It falsely suggests that our collective responsibility is to enable Indigenous nations to 'catch up' (Watene \& Yap, 2015) with the rest of Canada to support Canadian success within the global market economy. This is particularly troubling as a contradiction to Indigenous communities' deliberate efforts in the present day to rebuild Indigenous economies that were dismantled and outlawed by the federal government, such as formal potlatches and ceremonial feasting where relational economies come to life.

A second assumption is that reconciliation is about inclusion or exclusion of Indigenous peoples indicated by language choice to 'play a role' - language drawn from deficit discourses of development in the 1960s (Newhouse, 2004). However, agency has shifted from the federal government to business and industry proponents as the entities with power to determine the nature and extent of Indigenous inclusion or exclusion in the economy. In a hopeful bid to bring corporate Canada on board with reconciliation, the document assures the risk-averse business person that this process poses no risk to the economic status quo: "Business reconciliation requires a change in mindset away from risk management toward one of shared vision, strategic cooperation and business best practices that support the broader Canadian economy" [emphasis added] (Canadian Council for Aboriginal Business, 2019, pp. 9-10). It is further implied that with business best practices guiding this process, what can be assured is that by using 
normative business tools for success, reconciliation may even provide a competitive advantage to increase profits for companies that choose to engage in business reconciliation.

What both documents from 2009 and 2019 fail to mention is whether for Indigenous nations, playing a role in and supporting the Canadian economy advances Indigenous objectives akin to what Cardinal outlined 50 years prior toward sovereignty, self-determination, compensation for illegal land alienation, and reparations for harm done as a result of colonization. This is not to say that business reconciliation definitively does not achieve such aims. Still, these documents fail to outline in concrete terms what Indigenous aspirations are as autonomous and self-determining peoples, not solely as actors within the Canadian economy. Furthermore, by not specifying who relevant parties are in reconciliation, one is left to believe that reconciliation happens between the business community and Indigenous people in the business community without mentioning how either layperson Canadians and Indigenous people play a role in economic and business reconciliation. The absence of specified actors, their relationships and accountability to one another is a glaring omission. It leaves too great an opportunity for self-interested interpretations of economic success and extractive thinking to drive business reconciliation.

Additionally, the Business Reconciliation in Canada Guidebook (2019) contains an absence of clear distinctions between Indigenous aspirations and aspirations of the Canadian economy. If an implicit assumption is that the well-being of Canada's economy is the same as or equal to Indigenous well-being, historically, evidence shows that the opposite is true. The motivations for settler development since Europeans' arrival have consistently disregarded the cost to Indigenous well-being as a factor in Canada's construction and its economy as it is today. Key colonial activities sought to allow for the establishment and emergence of the Anglo-Western European economy of exploitation (Hyden, 1980) through overt oppression of Indigenous peoples and their values and fundamental freedoms (Rashbrooke, 2014). In Canada, Indigenous peoples hindered this process:

The Indians in the way were seen as obstacles to be cleared to realize the "National Dream" and, worse, as mere impediments to development and wealth-making. The fate of Indians caught by the western-rolling juggernaut of state, business, and settlement revealed that the goal of assimilating Indians did not signify any serious intent to integrate them as equals in Canadian society. They would be the targets of intense civilizing efforts, not to prepare them for good jobs and lives, but rather to erase their supposedly inferior ethnic traits. (Cunningham, 1999, p. 37)

Evidence of the experienced exploitative nature of settler economics is captured linguistically in changes within the Halq'eméylem language of the Stó:lō nations outside what is now Vancouver. The word xwelítem refers to settlers and translates as "the hungry people," describing the insatiable appetite of settlers for land, food and resources (Blomfield et al., 2001; Carlson, 2010; Stó:lō Nation Lalems ye Stó:lō Si:ya:m, 2003). The uncomfortable reality of 'unceded' and 'stolen land' across Canada continues to unearth deep-seated tensions about the 
legitimacy of Canadian prosperity against a backdrop of extractivist economics in a culture of never enough. This discomfort also masks a deeper conversation about the extent to which Canadian prosperity has produced and continues to produce Indigenous poverty as part of its ascent within the global market. Furthermore, to set the economic development bar for achievement at either participation or poverty alleviation is too low to be meaningful for longterm aspirations of Indigenous well-being.

One aspect of Indigenous well-being in practice is the ability to assert Aboriginal Rights (Delgamuukw v. British Columbia, 1997). However, time and time again, conflicts that emerge between Indigenous nations and (usually but not strictly) resource extraction industries concerning over-extraction is precisely due to fundamental disagreement between Indigenous well-being and Canadian economic well-being. Often Indigenous peoples are criminalized and find themselves opposing state police forces when they assert these rights - hardly evidence of industry or Canadian support of Indigenous well-being. To claim that Indigenous and Canadian economic well-being are the same in this form of economic relationship is simply untrue. Cardinal (1969) makes this point, but since 1969, the legal landscape has changed drastically with many successful Aboriginal Rights and Title cases that affirm Indigenous stewardship, longstanding responsibilities to traditional territories and waters, and economic rights to hunt, fish and gather (R. v. Marshall, 1999; UN General Assembly, 2007). Recognizing that the Business Reconciliation in Canada Guidebook (2019) is less a statement of fact, but more about efforts to manifest hopeful discourses of 'right relationship' that one day Indigenous well-being and Canadian economic well-being might align, even as aspirational documents, it hardly aligns with Indigenous advances in law, governance and political science research. The issue arises as to how Indigenous legal advances can and should translate into the world of business so that Indigenous aspirations are not subsumed under the hegemony of Canadian economic well-being.

From a different angle, the most common argument to explain and justify processes, decisions, and policies concerning Indigenous economic development focuses on poverty alleviation. As a progression from deficit discourse outlining the sad facts and figures regarding the state of Indigenous peoples after histories of genocide, attention and resources have shifted to solutions (Minister for Indian Affairs and Northern Development and Federal Interlocutor for Métis and Non-Status Indians, 2009). This line of thinking appears on both sides of the story - Indigenous and federal government - as emerging from a sentiment of "enough is enough" and fatigue in talking about the problems and the costs of Indigenous poverty to the Canadian public.

After many failed attempts by the government to devise and implement public policy and budgets for Indigenous economic and business development, economic development is now typical as a critical program for Indigenous nations to manage "on their own." Economic development committees, departments, corporations, programs, and officers occupy band offices all over the country. But this was not always so. Alongside federally mandated Indigenous management of Indigenous poverty, some access to capital and shifts in political will created economic opportunity in the 1990s. Joint ventures with early corporate opportunists (Anderson 
\& Bone, 1995; Anderson, 1997), evolving treaty environments (Anderson et al., 2004), the emergence of tribally-owned businesses (Cornell, 2006; Cornell \& Jorgenson, 2007), an assertion of sovereignty over lands outside of the treaty process (Anderson et al., 2006), and shifts within the Indian Act such as the ability for nations to pass bylaws and land codes created openings to new possibilities for nations that prior generations had not seen since colonization.

However, what is concerning about economic development as a pathway to poverty alleviation is that common sense logic carries overly simplistic rationale if the solution to poverty is profit. Inherent within this linear equation is an absence of understanding economic development as consisting of both means and ends that ultimately need to be aligned (Zamagni \& Zamagni, 2010). Furthermore, poverty alleviation requires a substantive and integrative approach to wealth distribution across multiple layers of society, including health, education, law, and cultural and social norms (Banerjee \& Duflo, 2012; Banerjee et al., 2019; Sen, 1999; Stiglitz, 2012). In Indigenous business development, the impetus for businesses and entrepreneurship might start by recognizing the need for poverty alleviation. Still, more often than not, once businesses generate profit, it goes back into business activities for further business growth and development, which is a marker of good business practice. In the case of two-thirds of business start-ups, business failure is counted as a learning opportunity. Unless there is a comprehensive plan for wealth distribution of profits from business activity targeted at poverty alleviation, and this plan is devised in tandem with business development planning, more often than not, profits do not translate into poverty alleviation, even with the best of intentions at the outset. The cycle of wealth creation and accumulation seals itself off from its distributive intentions.

Chickasaw and Cheyenne legal scholar, philosopher, and advocate Henderson (2000) critically analyzes the foundations of Eurocentric thought about human nature by philosophers John Locke and Thomas Hobbes, who consequentially are also philosophers whose thinking permeates modern-day market economics and Anglo-Western capitalism. Henderson and others (Coulthard, 2014; Williams, 2012) warn of the deeply flawed and problematic logic that underpins notions of modernity based on thinking grounded in false assumptions of Eurocentric superiority. Henderson (2000) argues that what is produced under that guise are artificial societies in which Indigenous inferiority is forever constructed and reconstructed in opposition to its dichotomous partner. Derivatives of this logic, including the dominant economic paradigm, serve to elevate, justify and perpetuate Eurocentric rationality and morality through constructs of scarcity and competition that consequently serve to divide and suppress irrational and immoral beings. In Henderson's (2000) critique of human nature's false construction, he advises that a remembering of Indigenous knowledges as not only a force for honouring Indigenous repositioning within human nature but as an honouring of reality and transformative ethical societies once again. Henderson (2000) says:

We must clearly understand the disadvantages of creating artificial societies from wrong assumptions. We should avoid affirming or copying the distorted European views of the state of nature or accommodating their made and imagined 'normal' 
social and political constructs. We must continue to see the organization of life in terms of the Indigenous knowledge about living in balance with an ecology. We must use our traditional knowledge and heritage to force a paradigm shift on the modernist view of society, self, and nature. (p. 31)

In circumstances where economic development comes into conflict with Indigenous laws, a popular argument frames Indigenous thinking as anti-capitalist. Iterations of this argument often unfold where extractive industry behaviours clash with Indigenous stewardship obligations. Whether it is the development of oil and gas, forestry, golf courses, fisheries, mining, or any other industry requiring access to Indigenous lands, rivers and oceans, inevitably those in favour of solely industry-driven development use the argument that Indigenous people need the products of extraction as much as anyone else. Therefore, anti-capitalist actions (such as blockades) are hypocritical. This might sound like, "We all use plastic, petrol, paper, etc. Resource extraction is a necessary process for our collective living." While partially true at this moment in time, a statement like this promotes static assumptions about reality - that it is unchanging. If what needs to change are our expectations of the conditions for collective living, then what is framed as necessary development processes now may not be in the future, just as they were not essential in the past either. In fact, what is essential in the future is unknown.

From a discursive standpoint, framing Indigenous opposition through a lens of hypocrisy is a simplistic effort at undermining Indigenous aspirations and rights by placing Indigenous actors within a patronizing narrative of the irrational emotional other (Williams, 2012). It also repositions industry actors at the centre of authority by access to knowledge that presumably informed an economic decision in the first place. This assumption about access to "elite" knowledge (Wade, 2015) reinforces imbalanced power relations in which Indigenous actors cannot have access to the same economic knowledge that industry actors can; and if they did, choosing not to develop proves the theory of Indigenous people as irrational emotional and therefore, inferior beings. Finally, it reinforces another assumption about Indigenous being in the present-day that pits culture and commerce as antithetical. In previous versions of this line of thinking, commerce might have been replaced with variations of 'modernity'. These are old versions of colonial arguments with long legacies that we will not rehash as this work has been argued substantively by decolonial scholars globally.

If one can rise above the emotionality of patronizing language, what this argument fundamentally closes down is the opportunity to engage Indigenous actors in a dialogue about ethical Indigenous economies and methods for achieving Indigenous well-being. The anti-capitalist argument sets up a false polarization between Indigenous and dominant economic thinking. Its overemphasis on 'the rejection' of development as evidence of Indigenous positionality on economics completely bypasses what might be a rejection of process rather than outcome. This is where a great deal of research and ancestral knowledge focused on long-term intergenerational thinking, traditional ecological knowledge (TEK) (Menzies, 2006), sustainability and ecological economics (Trosper, 2009) could come into play if the opportunity for dialogue about industry processes of extraction were on the table as a demonstration of economic reconciliation. 
Indigenous knowledge is increasingly available to the 'science' community in language that is recognizable to mainstream scientists. In other words, scholars have been researching and publishing by, for, and with Indigenous nations for several decades now. How Indigenous nations choose to codify this knowledge through language, spirituality, law and culture, and make this available to anyone or decide not to is entirely within the power and authority of those nations. However, because Indigenous knowledge is derived from the natural world, unlike the "science of the elite" in which economics counts itself (Wade, 2015), the fundamental source of Indigenous knowledge is the earth and the universe itself (Cajete, 1994, 1999; Hēnare, 2001). As Aleut Elder, Kuuyux (Ilarion Merculief) states:

Ancient peoples who still maintain their connection to the lands from which their ancestors came for millennia sustained an intimate connection, understand that it's the vibration of that place that actually informs my being and informs how the language is constructed, how it began, and how it has evolved...That vibration, when you are a real human being, you can feel it, it's palpable wherever you are on the land from which your ancestors have lived for thousands of years...The inherent intelligence of the real human being is the foundation and basis for us to live and thrive and communicate and connect with on a profound level with Mother Earth. (Merculief, 2012, p. 5)

The knowledge that Kuuyux refers to is not fundamentally exclusive, meaning that you must be a specific type of person or speak a certain language to understand it. As long as the natural world continues to exist, we can access our inherent intelligence because it comes from communicating and connecting with the natural world. However, if the state of the natural world is at significant risk of becoming inaccessible to the inherent intelligence of humanity due to its systematic destruction, and the cause of this destruction is over-exploitation by extractive industries, then the calculation of risk not just to Indigenous well-being but human well-being, in general, is factored into Indigenous decision-making. Thus, a decision not to support economic development in that form, at that particular time, speaks more to a higher possibility of solutions for alternative development than a lack of understanding development altogether. Seldom are Indigenous nations given the opportunity to spell out these important nuances, and if they are, they fall on deaf ears because what may present as a 'no' might mean 'not right now,' or 'not that way.'

In light of the approach to being and knowing that Kuuyux speaks to ancient societies, this question about whether Indigenous perspectives are deemed to be anti-capitalist or riddled with hypocrisy when analyzed through a trans-systemic Indigenous lens, they illuminate consistent pitfalls of Eurocentric logic. Returning to Henderson's (2000) argument about the self-reinforcing nature of Eurocentric philosophy, one finds that these threads continue to permeate discourses of economic development today to the detriment of meaningful reciprocal dialogue and engagement across Anglo-Western European and Indigenous knowledge systems hindering the potential for transformative insight into alternative approaches to economics and development. 


\section{Agency and Choice in Ethical Economies}

Trends in global economics look toward solutions beyond eradicating poverty with profit and move toward shifting institutional structures to prioritize human agency, choice and equality as mechanisms to leverage economic freedom (Sen, 1985). In light of the ongoing work to shift discourses around Indigenous economic development (Newhouse, 2004; Wuttunee, 2004), questions arise as to whether current approaches to Indigenous economic development adequately address ways to build economies that: facilitate economics that wholly engage Indigenous knowledge and therefore reflect Indigenous identities as people-centred economies (Hēnare, 2011, 2014; Nana, 2019b; Newhouse, 2004); recognize Indigenous definitions of wealth and existing methods of exchange (Dell et al., 2018; Kelly, 2017); and eradicate or reorganize institutional structures that continue to create Indigenous poverty (Dell, 2017; Hēnare, 2014; Nana, 2018).

In Indigenous contexts, processes of evaluative economic development based on what you are actually able to be and do extends far beyond subsistence measures of poverty alleviation. Economic freedom builds on the assumption that meeting basic needs alone does not generate the conditions for long-term aspirations to be realized because regardless of actual quality of life, the freedom to dream big is unaccounted for (Sen, 1999). Recent legal advances in AotearoaNew Zealand affirming the inherent agency and legal personhood of the Whanganui river itself protects the river as part of an extended kinship network (Argyrou \& Hummels, 2019). In this unprecedented example, the fundamental protections of agency and choice within the everyday human and "more-than-human" experience (Thomas, 2015) lend themselves to community and social entrepreneurship that fosters innovation and well-being. Because of protection from misuse and harm for both humans and more-than-humans, this inseparability of social, spiritual and economic well-being contributes to the enhancement and maintenance of Indigenous measures of wealth and freedom.

\section{Ethical Indigenous Economic Futures}

Utilizing trans-systemic Indigenous-to-Indigenous knowledge, we present select examples of Indigenous economic thought's contemporary articulations to lead new economic development directions. We highlight three key areas of insight that currently warrant greater emphasis and attention: 1) making visible the importance of spirituality within the lives of Indigenous people as economic actors, 2) accounting for intergenerational responsibility to ensure Indigenous economies are temporally aligned, and 3) giving priority to undervalued economic processes such as wealth distribution as contributing to the overall enhancement of Indigenous economic freedom.

\section{Spirituality in People-Centred Economies}

CEO and Founder of the Indigenomics Institute, Carol-Anne Hilton (2019) states, "We are a powerful people" (p. 110), promoting a shift away from deficit and exclusionary discourses about Indigenous people in Canada. In a refreshing approach grounded in her Nuu-chah-nulth Indigenous identity, Hilton draws on economic knowledge from potlatch traditions of wealth 
distribution to promote Indigenomics as an expression of ancient economic continuity contemporary and future-oriented at the same time. The resurgence of Indigenous economic thought re-centres kinship, intergenerational being and belonging as the drivers for economic development (Wuttunee, 2004). In other words, Indigenous economies position the means of economic development - entrepreneurship, business development, innovation, and financial growth - in service of Indigenous well-being ends (Nana, 2020). Most importantly, in Indigenous economies, the ends remain static and unchanging because philosophically, wellbeing ends are derived from universal ethics such as love, respect, humility, and reciprocity (Hēnare, 2003; Wuttunee, 2004). On the other hand, economic means are bound only by human agency and choice to determine pathways to well-being. Although it is compelling to believe that the dominant economic system is unchangeable due to the expansive institutions that currently support it, human-created systems are adaptable and changeable no matter how prevalent and persistent.

By and large, the most consistent theme emerging from newly articulated scholarship on Indigenous economies is the truism that at the heart of Indigenous economies are people as the greatest source of wealth and value. Research by Māori business scholar Dell (2017) demonstrates how the effects of alienation from lands and territories are shown qualitatively as negatively impacting Indigenous well-being today. As an economic concern, if the Māori economy represented by relationships to land continue to speak through Māori and Indigenous people as a source of pain and grief due to separation under often violent and dire circumstances (Kelly, 2017), the hidden cost of development is continued intergenerational trauma with each new advancement in land exploitation.

Māori business scholar, Mānuka Hēnare $(2011,2014)$ has theorized about the Māori economy as an economy of mana characterized by the following:

(a) it emanates from a Māori worldview and is informed by traditional Māori economics; (b) it is inspired by four well-beings—-spiritual, ecological, kinship, economic; (c) it is embedded in the ecological system that sustains it; (d) it requires a multidisciplinary approach to its research; (e) it is a system that is capable of reorganising itself to create new futures; and (f) it manifests as reciprocity and gift exchange. (Hēnare quoted in Dell et al., 2018, p. 55)

In Māori philosophy, mana is one aspect of a universal philosophy of humanism (Hēnare, 2001,2003 ) and resides in all things animate and inanimate as a potent manifestation of power. As a guiding principle within the economy of mana, a system of relational exchange emerges from the realization of power borne from inherent potentiality resulting from behaviours that enhance or detract from mana (Nana, 2019a). Thus, the purpose of economy for Māori is to facilitate the realization of the inherent power of all things - mana enhancement expressed through support and endorsement of others or mutual generosity. Therefore, mana as an achievement is recognized by the extent to which others can attest to one's generosity of spirit. Dell et al., (2018) contrast how an economy of mana differs from Anglo-Western economics 
in that economic decision-making is premised on principles of Māori wealth wherein its distribution ensures that mana is enhanced for everyone: "the economy of mana is stimulated by values of giving and abundance instead of ones that view resources as scarce" (p. 57).

In this version of Indigenous economic philosophy, people as economic actors are not driven by the transactions that occur within the economy; rather, preserving the integrity of both inherent potential power and realized power is given utmost priority. In an economy of mana, as a people- and land-centred economy, economic success results in the enhancement of power of humans and land. Economic downturns would result from unchecked detractors to or threats to people and land. Within the realm of Māori philosophy, mana is an inherently spiritual concept. Therefore, mana's economy is intrinsically spiritual by nature, which poses a challenge when questions arise around metrics and measuring an economy of mana. At the outset, the idea of measuring any aspect of spiritual life might cause discomfort, but with recent advances in development of Bhutan's Gross National Happiness Index for Business (Zhangmo et al., 2017), the release of New Zealand's Wellbeing Budget (New Zealand Government, 2019), and Iceland's Indicators for Well-being (Government of Iceland, 2019), another question arises as to whether spirituality is or can be separated from happiness or other interrelated well-being measures. It also leaves open the possibility that as long as spirituality remains invisible on the economic landscape, it never "counts" within the larger landscape of human well-being. This is an area for future research to contribute to this burgeoning field of Indigenous economies.

\section{Temporal Alignment}

One of the arguments that persists in the first half of this article is an implicit statement about the strategic deployment of time in service of particular discursive arguments. In the case of conflicts relating to resource extraction and Indigenous nations, linear time serves to reinforce economic development today without adequate consideration of the impacts on future generations. This leaves little opportunity for Indigenous economic actors to uphold intergenerational responsibilities because presentist arguments emphasize the imminent response needed to act within today's global market. What makes this possible are institutional incentives that reward opportunism and swift decision-making about investment of time and money.

Within the research community, though individual disciplines within management and organization studies research have shown greater propensity to account for long-term thinking and systems analysis, a significant amount of theoretical development continues to house inherent assumptions that we, meaning our current generation, is better, more innovative and learned than past generations. Such discourse promotes advances in theory and practice that are forward-facing and forever at the cutting edge of discovery in leadership, innovation, management, human resources, entrepreneurship, and institutional theory, to name a few. The normative intellectual culture of polarity, competition and comparative research is also aligned with the broader deficit discourse in economics that we have discussed throughout this article. We see a greater need for critical temporal perspectives that challenge overly presentist 
thinking in Indigenous business and economic research. A long-term and kin-based view (both metaphorical and literal in the case of Indigenous nations) does not inherently value the prosperity of today's generation over any other generation.

\section{Re-Valuing Wealth Distribution}

Moving away from emphasis on wealth accumulation as economic best practice, wealth distribution is a principle of Indigenous economics that is as old as Indigenous institutions (Hēnare, 2011; Kelly, 2017). At a practical level, institutional mechanisms that facilitate collective well-being effectively ensures individual well-being by default, whereas the reverse is not true. Returning to the potlatch system of Indigenous economics mentioned earlier, the literal and metaphorical ethic of feasting as an investment in both individual and collective futures is captured in a quote by the late Stó:lō Chief Richard Malloway who said, "Always feed your guests. When you do that, you will never go hungry" (Archibald, 2001, p. 26). By feeding other people through collective ceremonial and spiritual feasting, nurturing and normalizing the spirit of sharing shifts focus away from the negative effects of competition and exploitation that manifests within self-interest interpretations within neo-classical economics that drive the global market today.

One aspect of the sharing economy that aligns with Indigenous philosophies of wealth distribution is in cooperative organizations (Cheney et al., 2014; Peredo, 2003). Shifting assumptions about default business governance and its structures provide a mechanism to facilitate wider opportunities for Indigenous business ownership in which income distribution achieves greater breadth of impact to its beneficiaries (Findlay, 2018), occurs at an earlier stage of financial success than models of shareholder distribution through dividends, with more consistency throughout the lifespan of a business, and provides mechanisms for economic resilience, particularly in volatile labour market conditions (Zamagni \& Zamagni, 2010).

In the economy of mana (Dell et al., 2018), Māori wealth is based on value creation from enhancement of the inherent power of people and/or land. The creation of wealth in Māori economic development is a direct reflection of a Māori philosophy of well-being. It aligns with worldviews and principles that are recognizable in the past, present, and future. This example demonstrates validation of Indigenous economic knowledge centred on relationship, reciprocity and interconnectedness that ultimately fosters Indigenous economic freedom. Villanueva (2018) argues that to decolonize wealth, a re-framing of money is necessary. He challenges assumptions that money is inherently bad as a concept in and of itself and proposes that what needs to change are the structures and metrics of financial systems to better align with how money can be used ethically and responsibly. Fundamental financial institutional change will aid in better ways to distribute accumulated wealth for the well-being and benefit of Indigenous peoples (Villanueva, 2018). Eminent Indigenous singer-songwriter and activist Buffy Sainte-Marie spoke at the inaugural Indigenomics conference gala (Sainte-Marie, 2019) and set forth a reminder of the challenge that Indigenous peoples have always faced - that the institutional systems that facilitated dispossession and alienation from lands are not the systems that will enable Indigenous freedom, reconnection and decolonization. Heeding 
Sainte-Marie's call to redesign, reconnect, and decolonize Indigenous economies, the work ahead requires creative and generative commitment to centre Indigenous values and people, first and foremost.

\section{Conclusion}

Trans-systemic knowledge system analysis across Indigenous knowledges requires depth and considered thinking grounded in the very foundations of Indigenous ontology and epistemology. A trans-systemic knowledge method of analysis across global Indigenous economic knowledge systems facilitates alignment between Indigenous objectives of economic freedom and provides an avenue for collaboration, imagination, and decolonization of Indigenous economies. Part of a trans-systemic approach is exercising the freedom to choose among the philosophies upon which Indigenous aspirations of socio-cultural, spiritual, economic and ecological well-being are built. Engaging with diverse Indigenous perspectives utilizing a trans-systemic method provides insight into overlapping areas that support Indigenous economic thinking toward recovery from colonization and creating ethical economic institutions to support Indigenous aspirations for ethical economic futures.

This article has demonstrated differences in logic grounded in Anglo-Western Eurocentric economic development and explored discursive threads that persist over time in specific examples of reports focusing on Indigenous participation in the dominant Canadian economy. With examples from Indigenous philosophy and scholarship from North America and AotearoaNew Zealand, we discussed advances in Indigenous economic research that provide alternative ways of framing economies to account for people's inherent power and their relationships to land. We shed light on advances within global economics, focusing on substantive approaches to the eradication of poverty. We see an immediate need to shift economic development discourse in Canada from focusing on profit as an approach to poverty alleviation and see immense potential for a fulsome research agenda to further explore how Indigenous economics can better utilize measures of well-being and happiness in other national contexts as a way to Indigenous economic freedom and prosperity. 


\section{About the Authors}

Dara Kelly (corresponding author) is from the Leq'á:mel First Nation, part of the Stó:lō Coast Salish. She is an assistant professor of Indigenous Business at the Beedie School of Business, SFU. She teaches in the Executive MBA in Indigenous Business and Leadership program and on Indigenous business environments within full-time and part-time MBA programs. Dr. Kelly is a recipient of the 2020 Early in Career Award for c BC Distinguished Academic Awards. Her research helps fill in gaps in the literature on the economic concepts and practices of the Coast Salish and other Indigenous nations. She conducts research using research methodology emerging from Coast Salish philosophy, protocols and worldview. A paper stemming from her thesis won the Best Paper in Sustainability Award at the Sustainability, Ethics and Entrepreneurship (SEE) Conference in Puerto Rico in February 2017. She is cochair of the Indigenous Caucus at the Academy of Management and serves on the board of the Association for Economic Research of Indigenous Peoples. Email: dara_kelly@sfu.ca

Kiwi-born and bred, Christine Woods is an associate professor in entrepreneurship and innovation in the Faculty of Business \& Economics at the University of Auckland. Chris teaches entrepreneurship at the Undergraduate and Master's level and Māori Entrepreneurship, a component of the Postgraduate Diploma in Māori Business. Her research interests are in SME and family business, social entrepreneurship, and Māori entrepreneurship and entrepreneurial education. Chris is part of the ICEHOUSE Business Growth Programmes directing team, facilitating the Owner Manager Programme and does consultancy work with SMEs and Family Businesses and social enterprises. She is the founding director of Māori Maps (www.maorimaps.com).Email: cr.woods@auckland.ac.nz

\section{References}

Anderson, R. B. (1997). Corporate/Indigenous partnerships in economic development: The First Nations in Canada. World Development, 25(9), 1483-1503.

Anderson, R. B., \& Bone, R. (1995). First Nations economic development: A contingency perspective. The Canadian Geographer, 39(2), 120-130.

Anderson, R. B., Dana, L. P., \& Dana, T. E. (2006). Indigenous land rights, entrepreneurship, and economic development in Canada: "Opting-in" to the global economy. Journal of World Business, 41, 45-55.

Anderson, R. B., Honig, B., \& Peredo, A. M. (2006). Communities in the global economy: Where social and Indigenous entrepreneurship meet. In C. Steyaert (Ed.), Entrepreneurship as social change: A third movements in entrepreneurship book (pp. 56-78). Edward Elgar. 
Anderson, R. B., Kayseas, B., Dana, L. P., \& Hindle, K. (2004). Indigenous land claims and economic development: The Canadian experience. American Indian Quarterly, 28(3 \& 4), 634-648.

Archibald, J. (2001). Remembering the sacred time of elders: 25th annual gathering of First Nations elders silver anniversary souvenir book. Coqualeetza Cultural Education Centre.

Argyrou, A., \& Hummels, H. (2019). Legal personality and economic livelihood of the Whanganui River: A call for community entrepreneurship. Water International, 44(6/7), 752-768. https://doi.org/10.1080/02508060.2019.1643525

Banerjee, A. V., \& Duflo, E. (2012). Poor economics: A radical rethinking of the way to fight global poverty. Public Affairs.

Banerjee, A. V., Duflo, E., \& Kremer, M. (2019). Understanding development and poverty alleviation [The Committee for the Prize in Economic Sciences in Memory of Alfred Nobel]. Scientific Background on the Sveriges Riksbank Prize in Economic Sciences in Memory of Alfred Nobel 2019.

Bartlett, C., Marshall, M., \& Marshall, A. (2012). Two-Eyed Seeing and other lessons learned within a co-learning journey of bringing together Indigenous and mainstream knowledges and ways of knowing. Journal of Environmental Studies and Sciences, 2(4), 331-340.

https://doi.org/10.1007/s13412-012-0086-8

Battiste, M. (2013). Decolonizing education: Nourishing the learning spirit. Purich.

Blomfield, K., Boxberger, D. L., Carlson, K. T., Duffield, C., Hancock, R. L., Lutz, J., McHalsie, S., Ormerod, P., Peters, T., Rafter, T., Roburn, A., Schaepe, D. M., Smith, D., \& Woods, J. R. (2001). A Stó:lō-Coast Salish historical atlas (K. T. Carlson, C. Duffield, S. McHalsie, L. L. Rhodes, D. M. Schaepe, \& D. A. Smith, Eds.). Douglas \& McIntyre.

Cajete, G. (1994). Looking to the mountain: An ecology of Indigenous education. Kivaki Press.

Cajete, G. (1999). A people's ecology: Explorations in sustainable living. Clear Light.

Canadian Council for Aboriginal Business. (2019). Business reconciliation in Canada [Guidebook].

Canadian Council for Aboriginal Business.

Cardinal, H. (1969). The unjust society. M.G. Hurtig.

Carlson, K. T. (2010). The power of place, the problem of time: Aboriginal identity and historical consciousness in the cauldron of colonialism. University of Toronto.

Chen, M., \& Miller, D. (2010). West meets east: Toward an ambicultural approach to management. Academy of Management Perspectives, November, 17-24.

Cheney, G., Santa Cruz, I., Peredo, A. M., \& Nazareno, E. (2014). Worker cooperatives as an organizational alternative: Challenges, achievements and promise in business governance and ownership. Organization, 21(5), 591-603. https://doi.org/10.1177/1350508414539784

Colbourne, R. (2018). Chapter 4: Indigenous entrepreneurship and hybrid ventures. In A. C. Corbett \& J. A. Katz (Eds.), Advances in entrepreneurship, firm emergence and growth (Vol. 19, pp. 93-149). Emerald. https://doi.org/10.1108/S1074-754020170000019004

Cornell, S. (2006). What makes First Nations enterprises successful?: Lessons from the Harvard Project (pp. 1-20). Native Nations Insitute for Leadership, Management, and Policy.

Cornell, S., \& Jorgensen, M. (2007). The nature and components of economic development in Indian country (p. 22). National Congress of American Indians Policy Research Centre.

Coulthard, G. (2014). Red skin, white masks: Rejecting the colonial politics of recognition. University of Minnesota. 
Cunningham, A. (1999). Canadian Indian policy and development planning theory. Garland.

Delgamuukw v. British Columbia. (1997). Supreme Court of Canada. No. 23799. https://scc-csc. lexum.com/scc-csc/scc-csc/en/item/1569/index.do

Dell, K. (2017). Te Hokinga ki te Ükaipō: Disrupted Māori management theory, Harmonising whānau conflict in the Mãori land trust [Unpublished Doctorate of Philosophy]. University of Auckland.

Dell, K., Staniland, N., \& Nicholson, A. (2018). Economy of mana: Where to next? MAI Review, $7(1), 51-65$.

Findlay, I. (2018). Chapter 2 - Precursors to the Sharing Economy: Cooperatives. In P. Albinsson \& Y. Perera (Eds.), The rise of the sharing economy: Exploring the challenges and opportunities (pp. 9-28). Praeger.

Foley, D. (2003). An examination of Indigenous Australian entrepreneurs. Journal of Developmental Entrepreneurship, 8(2), 133-151.

Government of Iceland. (2019). Indicators for measuring well-being. Prime Minister's Office. Retrieved from https:/www.government.is/lisalib/getfile.aspx?itemid=fc981010-da09-11e9944d-005056bc4d74

Hēnare, M. (2001). Tapu, mana, mauri, hau, wairua: A Māori philosophy of vitalism and cosmos. In John A. Grim (Ed.), Indigenous traditions and ecology (pp. 197-221). Harvard University.

Hēnare, M. (2003). The changing images of nineteenth century Māori society: From tribes to nation [Unpublished Doctorate of Philosophy]. University of Wellington.

Hēnare, M. (2011). Lasting peace and the good life: Economic development and the "te atanoho" principle of Te Tiriti o Waitangi. In M. H. Tawhai \& K. Gray-Sharp (Eds.), “Always speaking": The Treaty of Waitangi and public policy (pp. 261-275). Huia.

Hēnare, M. (2014). The economy of mana. In D. Cooke, C. Hill, P. Baskett, \& R. Irwin (Eds.), Beyond the free market: Rebuilding a just society in New Zealand (pp. 65-69). Dunmore Press.

Henderson, J. Y. (2000). The context of the State of Nature. In M. Battiste (Ed.), Reclaiming Indigenous voice and vision (pp. 11-38). UBC Press.

Henry, E. (2007). Kaupapa Māori entrepreneurship. In L. P. Dana \& R. Anderson (Eds.), International Handbook of Research on Indigenous Entrepreneurship (pp. 536-548). Edward Elgar.

Henry, E. (2017). The creative spirit: Emancipatory Māori entrepreneurship in screen production in New Zealand. Small Enterprise Research, 24(1), 23-35. https://doi.org/10.1080/13215906.20 17.1289853

Hyden, G. (1980). The economy of affection. In Beyond Ujamaa in Tanzania: Underdevelopment and an uncaptured peasantry (pp. 18-19). University of California.

Hilton, C.-A. (2019). Indigenomics gala CEO address [Keynote, 25 June]. Indigenomics conference, Richmond, Canada.

Kahakalau, K. (2004). Indigenous heuristic action research: Bridging Western and Indigenous research methodologies. Hülili: Multidisplinary Research on Hawaiian Well-Being, 1(1).

Kelly, D. (2017). 'Feed the people and you will never go hungry': Illuminating Coast Salish economy of affection. [Unpublished Doctor of Philosophy], University of Auckland.

Maritz, A., \& Foley, D. (2018). Expanding Australian Indigenous entrepreneurship education ecosystems. Administrative Sciences, 8(2), 20. https://doi.org/10.3390/admsci8020020 
Merculieff, I. (2012). Going to the heart of sustainability: An Indigenous wisdomkeeper's perspective with Ilarion Merculieff [Speaker transcript, 12 May]. Kalliopeia Foundation, David Brower Centre, Berkeley, USA. Retrieved from https://vimeo.com/44699395

Menzies, C. (2006). Traditional ecological knowledge and natural resource management. University of Nebraska.

Minister of Indian Affairs and Northern Development and Federal Interlocutor for Métis and NonStatus Indians Canada. (2009). Federal framework for Aboriginal economic development. Ministry of Public Works and Government Services Canada.

Moustakas, C. (1990). Heuristic research: Design, methodology, and applications. Sage.

Nana, G. (2019a). BERL 2019 Wānanga - Value or values? Money or mana? Business and Economic Research Ltd. https://www.berl.co.nz/our-foundation/berl-2019-wananga-value-or-valuesmoney-or-mana

Nana, G. (2019b). Poverty, economics \& economists. Business and Economic Research. https://www. berl.co.nz/our-foundation/poverty-economics-economists

Nana, G. (2020). Economics as Kaitiakitanga o Taonga: Can we reverse the narrowing perspective of economics? Business and Economic Research. https://www.berl.co.nz/our-foundation/ economics-kaitiakitanga-o-taonga

Newhouse, D. (2004). The challenges of Aboriginal economic development in the shadow of the borg. Journal of Aboriginal Economic Development, 4(1), 34-42.

New Zealand Government. (2019). The well-being budget. New Zealand Government. Retrieved from https://treasury.govt.nz/sites/default/files/2019-05/b19-wellbeing-budget.pdf

Nicholson, A., Spiller, C., \& Pio, E. (2019). Ambicultural governance: Harmonizing Indigenous and western approaches. Journal of Management Inquiry, 28(1), 31-47. https://doi. org/10.1177/1056492617707052

Peredo, A. M. (2003). Emerging strategies against poverty: The road less traveled. Journal of Management Inquiry, 12(2), 155-166.

Peredo, A. M., Anderson, R. B., Galbraith, C. S., Honig, B., \& Dana, L. P. (2004). Towards a theory of Indigenous entrepreneurship. International Journal of Entrepreneurship and Small Business, 1(1/2), 1-20.

R. v. Marshall. (1999). Supreme Court of Canada. 260143 SCR 456. https://scc-csc.lexum.com/scccsc/scc-csc/en/item/1739/index.do

Rashbrooke, M. (2014). The inequality debate: An introduction. Bridget Williams Books.

Sainte-Marie, B. (2019). Indigenomics gala keynote: Buffy Sainte-Marie [Keynote, 25 June]. Indigenomics conference, Richmond, Canada. https://youtu.be/3rkDbO2xeoo

Sen, A. (1985). Well-being, agency and freedom: The Dewey Lectures 1984. Journal of Philosophy, 82(4), 169-221.

Sen, A. (1999). Development as freedom. Alfred A. Knopf.

Stiglitz, J. (2012). The price of inequality: How today's divided society endangers our future. W.W.

Norton \& Company.

Stó:lō Nation Lalems ye Stó:lō Si:ya:m. (2003). Stó:lō heritage policy manual. Stó:lō Nation Lalems ye Stó:lō Si:ya:m.

Thomas, A. (2015). Indigenous more-than-humanisms: Relational ethics with the Hurunui River in Aotearoa New Zealand. Social \& Cultural Geography, 16(8), 974-990. https://doi.org/10.108 0/14649365.2015.1042399 
Trosper, R. L. (2009). Resilience, reciprocity and ecological economics: Northwest Coast sustainability. Routledge.

Truth and Reconciliation Commission of Canada. (2015). Canada's residential schools: The history, part 1, origins to 1939 (Vol. 1). McGill-Queen's University Press.

UN General Assembly. (2007). United Nations Declaration on the Rights of Indigenous Peoples: Resolution/adopted by the General Assembly (A/RES/61/295). https:/www.refworld.org/ docid/471355a82.html

Villanueva, E. (2018). Decolonizing wealth: Indigenous wisdom to heal divides and restore balance. Berrett-Koehler.

Wade, R. (2015). How economists are failing society - Reflections on macroeconomics and income distribution. [Keynote, 2 December]. IKA Salon, Auckland, New Zealand.

Watene, K., \& Yap, M. (2015). Culture and sustainable development: Indigenous contributions. Journal of Global Ethics, 11(1), 51-55. https://doi.org/10.1080/17449626.2015.1010099

Williams, R. A. (2012). Savage anxieties: The invention of western civilization (1st ed). Palgrave Macmillan.

Wuttunee, W. A. (2004). Living rhythms: Lessons in Aboriginal economic resilience and vision. McGillQueen's University Press.

Zamagni, S., \& Zamagni, V. (2010). Cooperative enterprise: Facing the challenge of globalization. Edward Elgar.

Zhangmo, T., Wangdi, K., \& Phuntsho, J. (2017). Proposed GNH of Business. Centre for Bhutan Studies and GNH. http://www.bhutanstudies.org.bt/wp-content/uploads/2017/11/GNH-ofBusiness-.pdf 